University of South Carolina

Scholar Commons

1970

\title{
Electrochemical Reduction of Chromate in the Presence of Nickel Chloride in Molten Lithium Chloride-Potassium Chloride Eutectic
}

Branko N. Popov

University of South Carolina - Columbia, popov@engr.sc.edu

H. A. Laitinen

University of Illinois at Urbana

Follow this and additional works at: https://scholarcommons.sc.edu/eche_facpub

Part of the Chemical Engineering Commons

\section{Publication Info}

Journal of the Electrochemical Society, 1970, pages 482-484.

(c) The Electrochemical Society, Inc. 1970. All rights reserved. Except as provided under U.S. copyright law, this work may not be reproduced, resold, distributed, or modified without the express permission of The Electrochemical Society (ECS). The archival version of this work was published in the Journal of the Electrochemical Society.

http://www.electrochem.org/

DOI: $10.1149 / 1.2407546$

http://dx.doi.org/10.1149/1.2407546

This Article is brought to you by the Chemical Engineering, Department of at Scholar Commons. It has been accepted for inclusion in Faculty Publications by an authorized administrator of Scholar Commons. For more information, please contact digres@mailbox.sc.edu. 
22. F. C. Anson, R. F. Martin, and C. Yarnitzky, J. Phys. Chem., 73, 1835 (1969).

23. D. M. Mohilner in "Electroanalytical Chemistry," Vol. 1, p. 397, A. J. Bard, Editor, M. Dekker,
Inc., New York (1966).

24. F. Basolo and R. G. Pearson, "Mechanisms of Inorganic Reactions," p. 37, John Wiley \& Sons, Inc., New York (1967).

\title{
Electrochemical Reduction of Chromate in the Presence of Nickel Chloride in Molten Lithium Chloride-Potassium Chloride Eutectic
}

\author{
Branko Popor ${ }^{1}$ and H. A. Laitinen* \\ Department of Chemistry and Chemical Engineering, University of Illinois, Urbana, Illinois
}

\begin{abstract}
Chronopotentiometry of chromate in the presence of $\mathrm{NiCl}_{2}$ in molten $\mathrm{LiCl}$ $\mathrm{KCl}$ eutectic reveals a diffusion controlled, three electron reduction step. In the presence of excess $\mathrm{NiCl}_{2}$, chromate is reduced at $-0.35 \mathrm{~V} v \mathrm{~s}$. $\mathrm{Pt}(\mathrm{II}) / \mathrm{Pt}$ reference electrode and the electroactive species responsible for the chronopotentiometric wave is estimated to have a diffusion coefficient of $1.06 \cdot 10^{-5}$ $\mathrm{cm}^{2} \mathrm{sec}^{-1}$ at $450^{\circ} \mathrm{C}$. The stoichiometry of the reduction product depends mainly on the temperature at which the deposit is formed. At $500^{\circ} \mathrm{C}$ the deposit approaches the composition $\mathrm{LiNi}_{2} \mathrm{CrO}_{4}$. X-ray powder diffraction shows the deposit to be a single compound with a face centered cubic lattice. The length of the unit cell edge is estimated to be $4.14 \AA$. At $1400^{\circ} \mathrm{C}$ a weight loss of the deposit is observed. X-ray powder diffraction shows the presence of two phases, which are identified as $\mathrm{NiO}$ and $\mathrm{NiCr}_{2} \mathrm{O}_{4}$. The weight loss is attributed to volatization of $\mathrm{Li}_{2} \mathrm{O}$.
\end{abstract}

Laitinen and Propp (1) have shown that the electrochemical reduction product of $\mathrm{K}_{2} \mathrm{CrO}_{4}$ in $\mathrm{LiCl}-\mathrm{KCl}$ eutectic containing dissolved $\mathrm{MgCl}_{2}$ is a single unstoichiometric compound of formula $\mathrm{Li}_{x} \mathrm{Mg}_{y} \mathrm{CrO}_{4}$, where $x+2 y=5$. The values of $x$ and $y$ depended on the conditions of the electrolysis, namely current density, temperature, and the molar ratio of $\mathrm{Mg}$ (II) to $\mathrm{Cr}$ (VI) dissolved in the melt. Typical values of $x$ ranged between 0.3 and 0.5 .

Hanck (2) observed that the reduction of chromate in the presence of $\mathrm{Zn}$ (II) was shifted from $-1.0 \mathrm{~V} v s$. $\mathrm{Pt}$ (II) $/ \mathrm{Pt}$ reference to $-0.5 \mathrm{~V}$. Analysis of the deposit indicated the composition to be $\mathrm{LiZn}_{2} \mathrm{CrO}_{4}$. The stoichiometry of the compound was not affected by the electrolysis conditions.

The present investigation was undertaken to determine whether the reduction of $\mathrm{K}_{2} \mathrm{CrO}_{4}$ is affected by the presence of $\mathrm{NiCl}_{2}$ and to establish the composition of the reduction product. Spectrophotometric measurements failed to indicate any interaction between $\mathrm{Ni}$ (II) and chromate in the melt (3). $\mathrm{Ni}$ (II) is known to exist as stable chlorocomplexes (4) in chloride melts, and it was of interest to determine whether any chloride is contained in the deposit. Also the reduction potential of $\mathrm{Ni}$ (II) lies about $0.2 \mathrm{~V}$ below that of chromate in the absence of divalent ions and it was of interest to determine whether the deposition of metallic nickel could be avoided.

\section{Experimental}

Apparatus.-A Hevi-Duty MK 3012-S vertical split tube furnace (Hevi-Duty Electric Company, Watertown, Wisconsin) was utilized in this work. The temperature sensing element was a chromel alumel thermocouple (Onega Engineering, Inc., Springdale, Connecticut). All experiments were made at $450^{\circ} \mathrm{C}$ except as noted.

A Sargent Model IV coulometric current source was used for the electrolytic preparation of the electrode deposits. The constant current source for the chrono-

- Electrochemical Society Active Member.

I Present address: Faculty of Engineering, University of Skopje, Skopje, Yugoslavia. potentiometric studies has been described previously (1).

A Tektronix 503 oscilloscope served to record chronopotentiograms and to monitor the potential of the working electrode continuously during the preparation of the electrode deposits. The Pyrex cell and envelope have been described previously (5).

Electrodes.-The $\mathrm{Pt}$ indicator electrode used in this study has been previously described $(6)$. The electrode had a geometric area of $0.5 \mathrm{~cm}^{2}$ and was constructed so the glass metal seal was always kept above the level of the melt. The $\mathrm{Pt}$ (II)/Pt reference electrode was constructed as described by Ferguson (8).

The platinum gauze electrodes used to prepare samples of the film, as well as the carbon electrode which served as the counterelectrode in all electrochemical investigations in the melt, were constructed as described by Propp (1).

Chemicals.-All chemicals used in this study were reagent grade. Potassium chromate (J. T. Baker Chemical Company, Phillipsburg, New Jersey) was vacuum dried at $150^{\circ} \mathrm{C}$ before use. Anhydrous $\mathrm{NiCl}_{2}$ was prepared by heating the hexahydrate (J. T. Baker Chemical Company) in vacuum to $180^{\circ} \mathrm{C}$ over a three day period. Analysis indicated it to be $99.3 \%$ pure.

The $\mathrm{LiCl}-\mathrm{KCl}$ eutectic was obtained from Anderson Physics Laboratories, Inc., Champaign, Illinois. The method of purification has been described (7).

Solid chemicals were added to the melt by means of a small glass spoon. A blanket of argon was kept over the melt at all times to exclude oxygen and water vapor. The purification train used in purifying the argon has been described (8).

Experimental techniques.-Samples of the electrode deposit resulting from the reduction of chromate in the presence of $\mathrm{NiCl}_{2}$ were obtained by constant current electrolysis using platinum gauze electrodes. The gauze electrodes were cleaned in boiling $\mathrm{HClO}_{4}$, rinsed with distilled water, dried at $120^{\circ} \mathrm{C}$ for $16 \mathrm{hr}$, and weighed before their insertion into the molten salt solution. After electrolysis the gauze electrodes were 


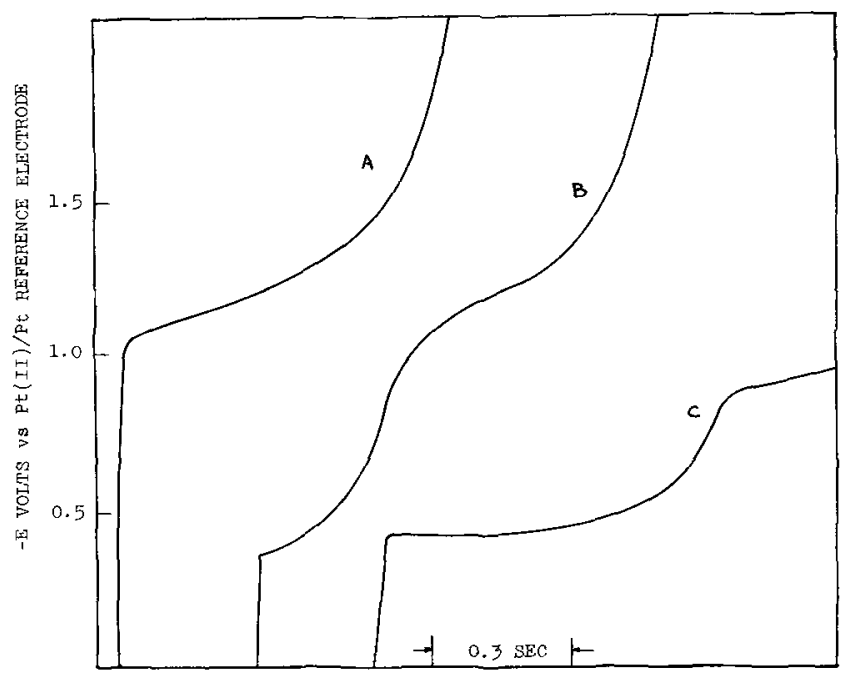

TIME

Fig. 1. Effect of nickel chloride concentration on reduction of chromate. $1.56 \times 10^{-2} \mathrm{M} \mathrm{K}_{2} \mathrm{CrO}_{4}$. A. No $\mathrm{NiCl}_{2} ;$ B. $7.29 \times 10^{-3} \mathrm{M}$ $\mathrm{NiCl}_{2} ;$ C. $3.28 \times 10^{-2} \mathrm{M} \mathrm{NiCl}_{2}$.

washed with deionized water, dried at $120^{\circ} \mathrm{C}$, and reweighed. The electrode deposits were dissolved in boiling $72 \%$ perchloric acid. The nickel content of the deposit was determined by an EDTA titration using a murexide indicator. The method chosen for the chromium determination is a modification of that of Meier, Myers, and Swift (9). The procedure used has been previously described (1). Lithium was quantitatively determined by flame photometry.

\section{Results and Discussion}

Chronopotentiometry of $\mathrm{K}_{2} \mathrm{CrO}_{4}-\mathrm{NiCl}_{2}-\mathrm{LiCl}-\mathrm{KCl}$ systems.-The effect of $\mathrm{Ni}$ (II) on the reduction of chromate was demonstrated by successively increasing the concentration of $\mathrm{Ni}$ (II) at constant chromate concentration. Figure 1 shows that at a Ni(II) concentration of $7.29 \cdot 10^{-3} \mathrm{M}$, two transitions were obtained: one at $0.35 \mathrm{~V}$ vs. $\mathrm{Pt}$ (II)/Pt reference and the other at $-1.0 \mathrm{~V}$. Additional increases in the nickel concentration caused the wave at $-0.35 \mathrm{~V}$ to grow larger. At a sufficiently high $\mathrm{Ni}$ (II)/Cr (VI) concentration ratio (2.1), the wave at $-1.0 \mathrm{~V}$ disappeared but a new wave appeared at approximately $-0.85 \mathrm{~V}$ which corresponds to the reduction of $\mathrm{Ni}$ (II). Further increase in the $\mathrm{Ni}$ (II) concentration had no influence on the first reduction step. This can be seen from the fact that identical transition times were obtained for $1.56 \times 10^{-2} \mathrm{M}$ $\mathrm{K}_{2} \mathrm{CrO}_{4}$ solution containing $3.28 \times 10^{-2} \mathrm{M} \mathrm{NiCl}_{2}$ and for one containing $5.6 \times 10^{-2} \mathrm{M} \mathrm{NiCl}_{2}$.

According to the Sand equation the product of $I \tau^{1 / 2}$ is independent of $I$ for a semi-infinite linear diffusion controlled process. The dependence of $I \tau^{1 / 2}$ on $I$ is demonstrated in Table $I$ for the reduction of $\mathrm{K}_{2} \mathrm{CrO}_{4}$

Table I. Chronopotentiometry of $\mathrm{K}_{2} \mathrm{CrO}_{4}$ in the presence of $\mathrm{NiCl}_{2}$

\begin{tabular}{|c|c|c|c|c|c|}
\hline \multicolumn{2}{|c|}{$E_{\tau} / 4=-0.35 \mathrm{~V}$} & \multicolumn{4}{|c|}{ Area of the Pt flag $=0.5 \mathrm{~cm}^{\mathrm{g}}$} \\
\hline $\begin{array}{c}C_{\mathrm{K}_{2} \mathrm{CrO}_{4}} \\
(\mathrm{M})\end{array}$ & $\underset{(\mathrm{M})}{\mathrm{C}_{\mathrm{NiCl}_{2}}}$ & $\stackrel{i}{i}$ & $\begin{array}{c}\tau^{1 / 2} \\
\left(\sec ^{1 / 2}\right)\end{array}$ & $\begin{array}{c}i \tau^{1 / 2} \\
\left(\mathrm{~A} \sec ^{1 / 2}\right)\end{array}$ & $\begin{array}{c}i \tau^{1 / 2} / C \\
(\mathrm{~A} \mathrm{sec} / 1 / 2 \\
\mathrm{cm}^{3} \\
\left.\text { mole }^{-1}\right)\end{array}$ \\
\hline $7.8 \times 10^{-3}$ & $1.34 \times 10^{-2}$ & $\begin{array}{l}6.625 \\
5.0 \\
4.0 \\
3.33\end{array}$ & $\begin{array}{l}0.497 \\
0.665 \\
0.850 \\
1.00\end{array}$ & $\begin{array}{l}3.29 \times 10^{-3} \\
3.25 \times 10^{-3} \\
3.40 \times 10^{-3} \\
3.33 \times 10^{-3} \\
3.20 \times 10^{-3}\end{array}$ & $\begin{array}{l}422 \\
426 \\
439 \\
427\end{array}$ \\
\hline $1.56 \times 10^{-9}$ & $5.67 \times 10^{-9}$ & $\begin{array}{l}8.0 \\
8.33 \\
10.0 \\
12.5\end{array}$ & $\begin{array}{l}0.80 \\
0.656 \\
0.53\end{array}$ & $\begin{array}{l}6.664 \times 10^{3} \\
6.56 \times 10^{-3} \\
6.63 \times 10^{-3}\end{array}$ & $\begin{array}{l}410 \\
426 \\
427 \\
424\end{array}$ \\
\hline $2.30 \times 10^{-2}$ & $5.67 \times 10^{-2}$ & $\begin{array}{l}12.5 \\
16.7 \\
18.94\end{array}$ & $\begin{array}{l}0.775 \\
0.565 \\
0.490\end{array}$ & $\begin{array}{l}9.68 \times 10^{-3} \\
9.50 \times 10^{-3} \\
9.77 \times 10^{-3}\end{array}$ & $\begin{array}{l}424 \\
421 \\
412 \\
425\end{array}$ \\
\hline $2.75 \times 10^{-2}$ & $5.67 \times 10^{-2}$ & $\begin{array}{l}14.3 \\
16.7 \\
18.94\end{array}$ & $\begin{array}{l}0.79 \\
0.67 \\
0.566\end{array}$ & $\begin{array}{r}11.3 \times 10^{-3} \\
11.25 \times 10^{-3} \\
11.30 \times 10^{-3}\end{array}$ & $\begin{array}{l}411 \\
410 \\
411\end{array}$ \\
\hline
\end{tabular}

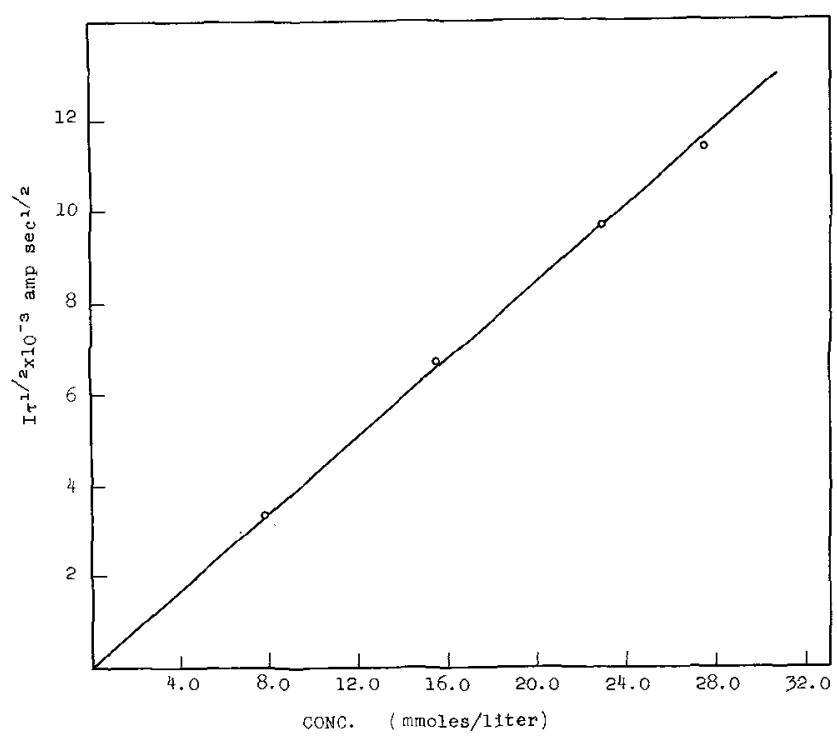

Fig. 2. Dependence of $1 \cdot \tau^{1 / 2}$ on concentration of $\mathrm{K}_{2} \mathrm{CrO}_{4} \cdot 0.5$ $\mathrm{cm}^{2} \mathrm{Pt}$ flag electrode. $\mathrm{C}_{\mathrm{NiCl}_{2}} / \mathrm{C}_{\mathrm{K}_{2} \mathrm{CrO}_{4}}>2.1$.

in the range of $7.8 \times 10^{-3} M$ to $2.75 \times 10^{-2} M$. The results indicate that the reduction of chromate in the presence of $\mathrm{Ni}$ (II) is diffusion controlled over the time interval investigated. Using $n=3$ from the controlled current coulometry, a value of $4.19 \pm 0.010$ - $10^{2} \mathrm{~A} \mathrm{sec} / 1 / 2 \mathrm{~cm}^{3} \mathrm{~mol}^{-1}$ for the transition time constant and $0.5 \mathrm{~cm}^{2}$ for the area of the electrode, we calculate $D=1.06 \pm 0.06 \cdot 10^{-5} \mathrm{~cm}^{2} \mathrm{sec}^{-1}$ for the chromate reduction in the presence of $\mathrm{Ni}$ (II) at $450^{\circ} \mathrm{C}$. From the slope in Fig. 2 (plot of $I \cdot \tau^{1 / 2} v s$. C) the same value for the diffusion coefficient was obtained.

In order to establish the chemical composition of the electrode deposit, samples of the deposit, which had been prepared by constant current electrolysis over a wide range of preparative conditions were analyzed. To guard against the deposition of metallic nickel, the potential of the working electrode never was allowed to become more cathodic than $-0.35 \mathrm{vs}$. $\mathrm{Pt}$ (II)/Pt. The influence of temperature, current density, and molar ratio of $\mathrm{Ni}$ (II) to $\mathrm{Cr}$ (VI) on the deposit composition was studied.

While holding the current density and the $\mathrm{Ni}$ (II) to Cr(VI) ratio constant, a series of deposits was prepared at $400^{\circ}, 450^{\circ}$, and $500^{\circ} \mathrm{C}$. The results of chemical analyses of these deposits are shown in Table II. From this table one can see that $\mathrm{Li}(\mathrm{I})$ content increases and the Ni(II) content correspondingly decreases as the temperature of the molten salt bath is increased. Table II also shows that the sum of the weight percentages of the three oxides, $\mathrm{NiO}, \mathrm{Li}_{2} \mathrm{O}$, and $\mathrm{Cr}_{2} \mathrm{O}_{3}$ is very close to $100 \%$, indicating that the chromium in the deposit is in the +3 oxidation state, and that no chloride or potassium ion is present. The absence of chloride in the deposit requires that the nickel chlorocomplex dissociate before the $\mathrm{Ni}$ (II) is incorporated into the deposit. That such a dissociation occurs rapidly enough to prevent inclusion of chloride in the deposit is remarkable. From Table II it is also obvious that in spite of the fact that the reduction potential of $\mathrm{Ni}$ (II) lies about $0.2 \mathrm{~V}$ below that of chromate in the absence of divalent metal ions, no evi-

Table II. Composition of electrode deposit as function of temperature

\begin{tabular}{|c|c|c|c|c|c|}
\hline \multicolumn{3}{|c|}{$\mathrm{C}_{\mathrm{K}_{2} \mathrm{CrO}_{4}}=0.052 \mathrm{M}$} & \multicolumn{3}{|c|}{$C_{\mathrm{N} 1_{1} \mathrm{Cl}_{2}}=0.198 \mathrm{M}$} \\
\hline $\begin{array}{l}\text { Temper- } \\
\text { ature } \\
\left({ }^{\circ} \mathrm{C}\right)\end{array}$ & $\begin{array}{l}\mathrm{Wt} \% \\
\mathrm{Li} 2 \mathrm{O}\end{array}$ & $\begin{array}{l}\text { Wt \% } \\
\text { Nio }\end{array}$ & $\begin{array}{l}\mathrm{Wt}_{\mathrm{t}} \% \\
\mathrm{Cr}_{2} \mathrm{O}_{3}\end{array}$ & Total \% & Formula \\
\hline $\begin{array}{l}400 \\
450 \\
500\end{array}$ & $\begin{array}{l}3.75 \\
4.09 \\
5.10\end{array}$ & $\begin{array}{l}66.8 \\
64.5 \\
64.0\end{array}$ & $\begin{array}{l}31.80 \\
30.60 \\
31.90\end{array}$ & $\begin{array}{r}102.0 \\
99.2 \\
101.0\end{array}$ & 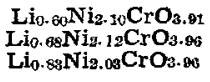 \\
\hline
\end{tabular}


dence to the deposition of metallic nickel was obtained. The empirical formula which best describes the deposit composition is $\mathrm{Li}_{x} \mathrm{Ni}_{y} \mathrm{CrO}_{4}$. As was observed by Propp (1) in his study of the $\mathrm{MgCl}_{2}-\mathrm{K}_{2} \mathrm{CrO}_{4}$ system, $x+2 y=5$ indicating that no oxide is lost during the electrolysis. At high temperature the deposit approaches the composition $\mathrm{LiNi}_{2} \mathrm{CrO}_{4}$.

Table III indicates that there is only a small change in the composition of the electrode deposit on changing the molar ratio of $\mathrm{Ni}$ (II) to $\mathrm{Cr}$ (VI). There is a slight decrease in $\mathrm{Li}(\mathrm{I})$ content and an accompanying increase in $\mathrm{Ni}$ (II) content as the molar ratio of $\mathrm{Ni}$ (II) to $\mathrm{Cr}$ (VI) is increased. The effect of current density on the composition of the electrode deposit on holding the temperature and the molar ratio of $\mathrm{Ni}$ (II) to Cr(VI) constant was observed and is indicated in Table IV. Current density in the range $1-10 \mathrm{~mA} / \mathrm{cm}^{2}$ does not appear to be a significant factor in determining the chemical composition of the electrode deposit.

$X$-ray powder diffraction studies.-Table $\mathrm{V}$ indicates that the deposit is a single compound with a face centered cubic lattice. The length of the unit cell edge is estimated to be $4.14 \AA$.

Thermal stability of electrode deposit.-A sample of deposit, while still on the platinum gauze electrode, was heated in air and in an argon atmosphere to $1000^{\circ} \mathrm{C}$ for a period of $48 \mathrm{hr}$. Weight losses were only $0.5 \%$ in argon and $0.04 \%$ in air. Chemical analyses on the heated samples were in agreement with the previous analyses of unheated samples The heated samples contained $3.87 \% \quad \mathrm{Li}_{2} \mathrm{O}, 66.7 \% \mathrm{NiO}$, and $37.50 \%$ $\mathrm{Cr}_{2} \mathrm{O}_{3}$ corresponding to the empirical formula $\mathrm{Li}_{0.60} \mathrm{Ni}_{2.11} \mathrm{CrO}_{3.91}$. The $\mathrm{x}$-ray powder pattern of the deposit appeared to change slightly after heating to temperatures above $950^{\circ} \mathrm{C}$. The original face centered cubic lines appeared to shift to give larger " $d$ " spacings and diffuse lines were observed at 4.788 and $2.494 \AA$.

A powdered sample of the deposit was heated to $1430^{\circ} \mathrm{C}$ in an air atmosphere. The $\mathrm{x}$-ray diffraction pattern of the heated sample is shown in Table VI.

The pattern shows the presence of two phases; a diamond cubic phase with a unit cell edge of $8.305 \AA$ and a face centered cubic phase with a unit cell edge

Table III. Composition of electrode deposit as function of $\mathrm{NiCl}_{2}$ concentration

\begin{tabular}{|c|c|c|c|}
\hline \multicolumn{2}{|c|}{ Temperature $=450^{\circ} \mathrm{C}$} & \multirow[b]{2}{*}{ Total Wt $\%$} & \multirow{2}{*}{$\begin{array}{c}I=1.26 \mathrm{~mA} / \mathrm{cm}^{2} \\
\text { Formula }\end{array}$} \\
\hline $\mathrm{C}_{\mathrm{K}_{2} \mathrm{CrO}_{4}}, M$ & $\mathrm{C}_{\mathrm{NiCl}_{2}}, \mathrm{M}$ & & \\
\hline $\begin{array}{l}0.078 \\
0.068 \\
0.058 \\
0.056\end{array}$ & $\begin{array}{l}0.152 \\
0.225 \\
0.312 \\
0.481\end{array}$ & $\begin{array}{r}100.1 \\
99.8 \\
99.1 \\
99.0\end{array}$ & $\begin{array}{l}\mathrm{Li}_{0.71} \mathrm{Ni}_{2.09} \mathrm{CrO}_{3.94} \\
\mathrm{Li}_{0.67} \mathrm{Ni}_{2.10} \mathrm{CrO}_{3.9} \\
\mathrm{Li}_{0.62 \mathrm{Ni}_{2.12} \mathrm{CrO}_{3.94}} \mathrm{Li}_{0.62} \mathrm{Ni}_{2.18} \mathrm{CrO}_{3.98}\end{array}$ \\
\hline
\end{tabular}

Table IV. Effect of current density on composition of electrode deposit

\begin{tabular}{|c|c|c|}
\hline $\mathrm{C}_{\mathrm{K}_{\mathrm{g}} \mathrm{CrO}_{4}}=0.0482 \mathrm{M}$ & $C_{\mathrm{NiCl}_{2}}=0.124 M$ & Temperature $=450^{\circ} \mathrm{C}$ \\
\hline $1, \mathrm{~mA} / \mathrm{cm}^{2}$ & Total Wt \% & Formula \\
\hline $\begin{array}{l}1.21 \\
2.82 \\
4.31 \\
9.82\end{array}$ & $\begin{array}{l}99.2 \\
99.2 \\
98.5 \\
98.9\end{array}$ & $\begin{array}{l}\mathrm{Li}_{0.66} \mathrm{Ni}_{2.18} \mathrm{CrO}_{3.9} \\
\mathrm{Li}_{0.68} \mathrm{Ni}_{2.19} \mathrm{CrO}_{4.00} \\
\mathrm{Li}_{0.58 \mathrm{Ni}_{2.20} \mathrm{CrO}_{3.90}} \mathrm{Li}_{0.58} \mathrm{Ni}_{2.10} \mathrm{CrO}_{3.98}\end{array}$ \\
\hline
\end{tabular}

Table V. X-ray data for electrode deposit

\begin{tabular}{lrll}
\hline$d(\AA)$ & $I / I_{0}$ & $h k l$ & $a(\AA)$ \\
\hline 2.3840 & 60 & 111 & 4.129 \\
2.0657 & 100 & 200 & 4.137 \\
1.4622 & 60 & 220 & 4.136 \\
1.2476 & 30 & 311 & 4.178 \\
1.1957 & 20 & 222 & 4.1403 \\
1.0352 & 10 & 400 & 4.141
\end{tabular}

Table VI. X-ray powder pattern of electrode deposit heated to $1430^{\circ} \mathrm{C}$

\begin{tabular}{cc}
\hline$d(\mathrm{~A})$ & $1 / I_{\mathrm{o}}$ \\
\hline 4.7533 & 10 \\
2.9180 & 15 \\
2.493 & 100 \\
$* 2.4024$ & 60 \\
22.0798 & 40 \\
2.0650 & 20 \\
1.6960 & 30 \\
1.5938 & 80 \\
$* 1.4730$ & 20 \\
1.4696 & 100 \\
1.2635 & 10 \\
$* 1.2599$ & 25 \\
1.207 & 10 \\
1.0798 & 10 \\
\hline
\end{tabular}

* Face centered cubic lines.

of $4.169 \AA$. The face centered cubic phase corresponds reasonably well to $\mathrm{NiO}(a=4.176 \AA)$ and the diamond cubic phase to $\mathrm{NiCr}_{2} \mathrm{O}_{4}(a=8.32 \AA)$. No lines were observed which could be assigned to the unheated nickel compound or to pure $\mathrm{Li}_{2} \mathrm{O}$.

Chemical analyses of the electrode deposit heated to $1400^{\circ} \mathrm{C}$ are in agreement with $\mathrm{x}$-ray data. The deposit contained $67.01 \% \mathrm{NiO}, 32.3 \% \quad \mathrm{Cr}_{2} \mathrm{O}_{3}$, and no $\mathrm{Li}_{2} \mathrm{O}$, which corresponds to the empirical formula $\mathrm{Ni}_{2.11} \mathrm{CrO}_{3.61}$.

The empirical formula of an unheated sample was found to be $\mathrm{Li}_{0.7} \mathrm{Ni}_{2.10} \mathrm{CrO}_{4}$. If the $\mathrm{Li}_{2} \mathrm{O}$ is lost during heating, the remainder of the compound must have the empirical formula $\mathrm{Ni}_{2.10} \mathrm{CrO}_{3.6}$ which is in agreement with chemical analyses of the heated sample.

Manuscript submitted Sept. 23, 1969; revised manuscript received ca. Dec. 1, 1969.

Any discussion of this paper will appear in a Discussion Section to be published in the December 1970 JOURNAL.

\section{REFERENCES}

1. H. A. Laitinen and J. H. Propp, Anal. Chem., 41, 645 (1969).

2. K. W. Hanck, Ph.D. Thesis, University of Illinois, (1969).

3. K. W. Hanck, Personal communication, unpublished results.

4. J. Brynestad, C. R. Boston, and G. P. Smith, J. Chem. Phys., 47, 3179 (1967).

5. H. A. Laitinen and W. S. Ferguson, Anal. Chem., 29, 4 (1957).

6. H. A. Laitinen and R. D. Bankert, ibid., 39, 1790 (1967).

7. H. A. Laitinen, R. S. Tisher, and D. K. Roe, This Journal, 107, 546 (1960).

8. W. S. Ferguson, Ph.D. Thesis, University of Illinois

9. D. J. Meier, R. T. Myers, and E. H. Swift, J. Am. Chem. Soc., y1, 2340 (1949). 